\title{
Teacher provision of opportunities for learners to develop Language Knowledge and Cultural Knowledge
}

Clare Conway, Heather Richards, Sharon Harvey, Annelies Roskvist

School of Languages and Social Sciences, Auckland University of Technology, Auckland, New Zealand

Clare Conway, School of Languages and Social Sciences, Auckland University of Technology, Private Bag 92006, Auckland 1142, New Zealand. clare.conway@aut.ac.nz

Heather Richards, School of Languages and Social Sciences, Auckland University of Technology, Private Bag 92006, Auckland 1142, New Zealand. heather.richards@aut.ac.nz

Sharon Harvey, School of Languages and Social Sciences, Auckland University of Technology, Private Bag 92006, Auckland 1142, New Zealand. sharon.harvey@aut.ac.nz

Annelies Roskvist, School of Languages and Social Sciences, Auckland University of Technology, Private Bag 92006, Auckland 1142, New Zealand. annelies.roskvist@aut.ac.nz Author responsible for correspondence:

Clare Conway, School of Languages and Social Sciences, Auckland University of Technology, Private Bag 92006, Auckland 1142, New Zealand. 


\section{Abstract}

This paper examines a language teacher education professional development programme in New Zealand that draws on The New Zealand Curriculum (2007) (Ministry of Education, 2007a). At the heart of the Learning Languages area in the curriculum is communicative competence with the understanding that communication involves Language Knowledge and Cultural Knowledge. The New Zealand Ministry of Education expects schools will offer all Year 7-10 students the opportunity to learn an additional language in order for them to participate effectively in multicultural settings, both in New Zealand and internationally. To deliver the Learning Languages area of the curriculum, language teachers and generalist teachers are being encouraged to undertake professional development. This paper reports on a research evaluation of a Ministry-sponsored language teacher professional development programme. The findings reveal success in increasing teacher understanding of how to develop learners' Language Knowledge, because this part of the programme was underpinned by a deep principled knowledge base (Timperley, Wilson, Barrar \& Fung, 2007), and teachers had opportunities to "acquire” knowledge and "participate” in a language teaching community (Sfard, 1998). However, teacher understanding of how to increase learners' Cultural Knowledge was less successful, because of a lack of a principled knowledge base of intercultural language teaching. We argue that effective professional development programmes need to both be based on deep principled knowledge and to offer learning that involves acquisition and participation.

Keywords: language teaching; professional development; intercultural language teaching; knowledge; principles 


\section{Introduction}

The New Zealand Curriculum (2007) for teaching and learning in English medium schools now places learning languages (in addition to Maori and English) in a curriculum area in its own right, thereby according language learning a higher status than previously (Ministry of Education, 2007a). One reason for promoting language learning is to enable students to participate more actively in diverse multicultural settings (Education Review Office, 2009). The heightened status and the expectation that schools will be able to offer additional languages to all Years 7-10 students (those aged 10-14), has resulted in a need for a greater number of language teachers in New Zealand. The Ministry of Education has sponsored a programme aimed at upskilling language teachers and encouraging generalist teachers to become language teachers. If, as Sfard suggests, the essence of learning is "our ability to prepare ourselves today to deal with new situations we are going to encounter tomorrow” (1998, p.9), then it is important to know how well these teachers are learning to teach languages and preparing language learners for the future In 2008 we were asked to evaluate the Ministry sponsored professional development programme (Harvey, Conway, Richards \& Roskvist, 2009). This paper examines one aspect of our evaluation - teachers' provision of opportunities to develop learners' Language Knowledge and Cultural Knowledge as outlined in the Learning Languages area of The New Zealand Curriculum (2007) (Ministry of Education, 2007a). We argue that an effective professional development programme needs to both be based on deep principled knowledge and to offer learning that involves acquisition and participation.

\section{Effective Professional Development}

Teacher educators concerned with effective ways to develop teachers' knowledge on professional development courses need to consider the theoretical foundation of the course 
and theories of learning to ensure that the course is not just a series of workshops demonstrating isolated techniques. A key component of a course that sustains learning is a foundation of deep principled knowledge (Timperley Wilson, Barrar and Fung, 2007) which provides a conceptual framework to support both pedagogical and content knowledge. A conceptual framework enables learners to organise their knowledge for retrieval and application (Bransford, Brown and Cocking, 1999). And the language teacher who is supported by principled knowledge base from the start of the course can see patterns and recognise what is consistent in their learning in order to change and develop their practice (Timperley et al. 2007). Courses may have a strong foundation of knowledge, but a further factor for educators to consider is theories of learning and how the knowledge base is best delivered to participants. Sfard (1998) suggests that metaphors are beneficial for describing theories of learning as they "guide us in our work as learners, teachers and researchers" (p.5). Two metaphors discussed in her seminal work are the Acquisition Metaphor (AM) and the Participation Metaphor (PM). Historically, under the AM, learning is viewed as a cognitive process where students acquire knowledge with the goal of individual enrichment. The student is seen as a recipient, consumer, constructor and reconstructor of knowledge, which is perceived as a possession to be applied in other situations. In the PM, which has emerged more recently, learning is viewed as a social process with the goal of becoming part of a community. The student is seen initially as a "peripheral participant” (p.7) or apprentice. Knowing in the PM is about belonging, participating and communicating. "From a lone entrepreneur, the learner turns into an integral part of a team” (p.6). Although Sfard describes the metaphors of learning individually, she admits it is difficult to separate them in educational programmes. They are not mutually exclusive, and some learning frameworks may have a greater focus on acquisition, or alternatively display a preference for participation. These metaphors and the aforementioned principled knowledge base form a 
platform on which to examine the success of a language teacher professional development programme in preparing teachers to provide opportunities for learners to develop Language Knowledge and Cultural Knowledge.

\section{Context}

\section{The New Zealand Curriculum}

Central to the Learning Languages area in The New Zealand Curriculum (2007) (Ministry of Education, 2007a) is Communicative Competence supported by Knowledge Awareness with two equally weighted strands: Language Knowledge and Cultural Knowledge.

According to the Generic Framework for Learning Languages (Ministry of Education, 2007b), to develop Language Knowledge students:

... study the language in order to understand how it works. They learn about the relationships between different words and different structures, how speakers adjust their language when negotiating meaning in different contexts and for different purposes, and how different types of text are organised. This strand helps students to develop specific knowledge of the language which over time will contribute to greater accuracy of use (p.1).

Cultural Knowledge involves students learning about:

the interrelationship between culture and language. [Learners] grow in confidence as they learn to recognise different elements of the belief systems of speakers of the target language. They become increasingly aware of the ways in which these systems are expressed through language and cultural practices (p.1).

Language Knowledge is clearly described in terms of four key elements students will study (structures, words, adjustment of language to negotiate meaning, and text organisation) with the aim of improving the learners' knowledge and accuracy of language use. Cultural 
Knowledge mentions two elements for study (beliefs and cultural practices), but also is concerned with the learners' affective behaviour (a growth in confidence and a greater awareness of self and others) which is harder to measure and define. This strand of the framework may thus appear less clear than Language Knowledge and in turn more difficult for teacher educators and teachers to interpret.

The understanding that communication involves both Language Knowledge and Cultural Knowledge is not new within language teaching. New Zealand Ministry of Education language teaching resources such Hai! An introduction to Japanese (Ministry of Education, 1999) have supported language teachers in developing both Language Knowledge and Cultural Knowledge. However, the main focus in these resources has been on language development, with some accompanying cultural content. Cultural Knowledge is mainly around cultural activities and practices (eg. the preparation and consumption of food) rather than looking beyond practice to the belief systems of target language (TL) speakers. An important development in the New Zealand language learning and teaching context is an expanded understanding of how cultural practices relate to beliefs, and that studying language and culture can lead to a greater awareness not only of others but also of oneself. An understanding of both self and others can in turn lead to language learners as intercultural speakers who can successfully engage with others across boundaries (Byram, 1995). Intercultural competence is desirable for developing language learners' positive attitudes towards others (Nikolov \& Djigunović, 2006); enabling learners to view the world through different eyes (Bennett, Bennett \& Allen, 2003); and helping them to "understand more about themselves and become more understanding of others” (Ministry of Education, 2007b, p.1). Thus, Cultural Knowledge now includes the concept of developing learners' intercultural competence and, with this expanded understanding, there is the expectation that teacher development programmes will cater for these new professional demands (Sercu, 2006). 


\section{The professional development programme}

The one year part-time professional development programme we evaluated for the New Zealand Ministry of Education (Harvey, Conway, Richards \& Roskvist, 2009), was for teachers teaching one or more of five additional languages: Chinese, French, German, Japanese and Spanish. The programme was aimed at developing teachers' competence to teach the Learning Languages area of The New Zealand Curriculum (2007) (Ministry of Education, 2007a) and had three inter-related components. These were: Language Study, Second Language Acquisition (SLA) and In-School Support. In the Language Study component, teachers learned their teaching language for at least one semester through a local provider, such as a community night class, or through a credit bearing course at a tertiary institution, either online or face-to-face. Teachers also met four times a year in language group meetings to study and discuss the principles of SLA, and also to prepare to sit an internationally recognised TL exam. In the second component, Second Language Acquisition, teachers deepened their knowledge of language learning and teaching through studying a credit-bearing university paper. They studied SLA theory, explored new Learning Languages area of The New Zealand Curriculum (2007) and developed classroom pedagogy, strategies and resources. Teachers planned and assessed units of work for diverse learners, as well as completing an action research project. The third component, In-School Support, was provided by programme facilitators through four observations of teaching, and follow-up discussion that focused on maximising student learning outcomes. A specific programme website also provided course materials and further information for participants.

\section{Research Design}

The full evaluation of the professional development programme (Harvey, Conway, Richards \& Roskvist, 2009) was based on data gathered from three surveys of course participants ( $\mathrm{n}=$ 
25), as well as face-to-face interviews and observations of seven teachers, and additional data from programme documents and Milestone reports which were submitted to the Ministry of Education by the professional development contractor. The seven teachers were selected to ensure a wide mix of the following variables: geographical area in New Zealand, type of school, school decile rating (low to high on a socio-economic scale), school community (rural, small town, large city), level of students (ages 11-14), language taught (Chinese, French, German, Japanese or Spanish) and level of teacher's language teaching experience (first year through to five years). All teachers had English as their first language. Each participant was interviewed and observed three times during the year with their own class of language learners. The interview questions were semi-structured, enabling the researchers to probe teachers' developing understandings and gather their feelings, views and attitudes. Key interview questions included asking teachers about their developing knowledge of second language acquisition, classroom pedagogy and The New Zealand Curriculum (2007) (Ministry of Education, 2007a). Observation prompts based on effective language teaching practice were developed from key literature (Krashen, 1981; Erlam, 2005; Gibbs \& Holt, 2003; Ellis, 2005; Crozet \& Liddicoat, 1999). All data were recorded as hand-written notes and later written into electronic data files. From the full evaluation, we examine one aspect here, i.e. what opportunities teachers provided for learners to develop Language Knowledge and Cultural Knowledge as outlined in above. We draw on data from the seven teachers observed and interviewed, and from relevant programme documents.

\section{Teacher provision of opportunities to develop learners' Language Knowledge}

From the beginning of the course, teachers indicated in interview that they were focussing on developing learners’ Language Knowledge drawn from SLA principles (Ellis, 2005). One teacher articulated the relationship between the principles and her developing practice, saying “When doing my lesson plan, I’m keeping in mind the principles and thinking of where I 
have, in my lesson, the input; the output; the formulaic expressions; the meaningful context.” Lesson aims were focussed on learning and practising new vocabulary and formulaic expressions, and introducing or revising items of grammar. As well, aims were related to developing learner confidence and oral production. Observation data confirmed this. By the end of the course, all seven teachers were observed applying key second language learning principles to their instruction. Table 1 outlines how one teacher, typical of the cohort, was observed putting these principles into practice in her final observed lesson.

Table 1. Example of one teacher’s application of instructed second language learning principles (Ellis, 2005).

\begin{tabular}{ll}
\hline Teacher & Observation 3: Main principles observed \\
\hline Teacher & Input - T provided high level of TL input through audio texts, reading text as well as through \\
& extensive use of TL for classroom management, instructions, social goals. \\
& Interaction - T provided opportunities for SS to interact in TL in groups. \\
& Output - T provided many opportunities for output, oral and written. \\
& Meaning - T provided focus on meaning through SS discussion and categorisation of vocabulary. \\
& Form - T provided some opportunities for focus on form (pronunciation).
\end{tabular}

\section{Notes:}

1. T Teacher SS Students TL Target Language

This teacher demonstrated application of the principles (Ellis, 2005), as did all teachers. They were observed providing learners with a high level of target language input through the use of formulaic expressions, and using the target language to manage the class, give instructions, and achieve social goals. Teachers also provided opportunities for learners to interact in the TL to develop their proficiency, and learners had many opportunities for both oral and written output. In addition, the key principles of focus on meaning and focus on form were well demonstrated by all teachers. One teacher was also noted using a higher level of the TL to cater for her learners’ increasing Language Knowledge.

Both the interview and observation data indicated that the programme effectively developed teachers’ ability to provide opportunities for their learners to develop Language Knowledge. 


\section{Teacher provision of opportunities to develop learners' Cultural Knowledge}

While observation data indicated the programme had a clear positive impact on the teachers' provision for learners to develop Language Knowledge, the results were less positive for the development of learners’ Cultural Knowledge. Cultural Knowledge, as mentioned earlier, embraces intercultural competence and is demonstrated through learners making connections between cultures, comparing and contrasting cultural practices, linking culture and language, reflecting on their own culture through the eyes of others and having opportunities to interact in a culturally competent way with a TL community. To evaluate teachers' observed provision of opportunities to develop learners' Cultural Knowledge we devised an observation framework based on relevant theory. We have called this the Intercultural Language Learning (IcLL) framework. It was informed by requirements of The Generic Framework for Learning Languages (Ministry of Education, 2007b), as well as the work of Kramsch, (1993); Byram, (1995); Crozet and Liddicoat, (1999); Papademetre, Scarino and Kohler, (2003); Elsen and St John, (2006). The IcLL framework was used to analyse data from all teacher observations, examining the extent to which they provided opportunities for their learners to develop Cultural Knowledge. By the end of the course, there was limited evidence of teachers encouraging learners to develop this knowledge strand. Table 2 shows how even the most accomplished teacher was working in only some areas. 
Table 2. An accomplished teacher’s application of aspects of intercultural language learning

\begin{tabular}{|c|c|c|c|c|c|}
\hline \multirow[b]{2}{*}{ Categories } & \multicolumn{5}{|c|}{ Intercultural Language Learning (IcLL) Framework } \\
\hline & Make connections & Compare \& contrast & $\begin{array}{l}\text { Link culture \& } \\
\text { language }\end{array}$ & $\begin{array}{l}\text { Reflect on own } \\
\text { culture }\end{array}$ & $\begin{array}{l}\text { Intercultural } \\
\text { competence }\end{array}$ \\
\hline & $\begin{array}{l}\text { Teacher provides opportunities } \\
\text { for learners to make } \\
\text { connections with known } \\
\text { cultures }\end{array}$ & $\begin{array}{l}\text { Teacher provides } \\
\text { opportunities for } \\
\text { learners to compare and } \\
\text { contrast cultural } \\
\text { practices and make } \\
\text { meaning }\end{array}$ & $\begin{array}{l}\text { Teacher provides } \\
\text { opportunities for } \\
\text { learners to make } \\
\text { links between } \\
\text { culture and } \\
\text { language and make } \\
\text { meaning }\end{array}$ & $\begin{array}{l}\text { Teacher provides } \\
\text { opportunities for } \\
\text { learners to reflect } \\
\text { on own culture(s) } \\
\text { through eyes of } \\
\text { others. }\end{array}$ & $\begin{array}{l}\text { Teacher provides } \\
\text { opportunities for } \\
\text { learners to } \\
\text { interact in a } \\
\text { culturally } \\
\text { competent way } \\
\text { with a TL } \\
\text { community }\end{array}$ \\
\hline Teacher & $\begin{array}{l}\text { - T made links between } \\
\text { English fairy tales students } \\
\text { were familiar with, and TL } \\
\text { fairy tales, using map of TL } \\
\text { country to show where } \\
\text { story took place. } \\
\text { - T asked students what they } \\
\text { ate for breakfast before they } \\
\text { researched what TL. } \\
\text { speakers have for breakfast } \\
\text { - T asked students about the } \\
\text { number of Olympic medals } \\
\text { NZ had before students } \\
\text { researched TL country } \\
\text { medals score. }\end{array}$ & $\begin{array}{l}\text { - T compared use of } \\
\text { buses in TL country } \\
\text { and in NZ (eg. } \\
\text { notions of } \\
\text { punctuality) and } \\
\text { students noted the } \\
\text { differences in } \\
\text { transport. } \\
\text { - T asked 'Did you } \\
\text { notice animals make } \\
\text { different sounds in } \\
\text { TL (than in } \\
\text { English)?' } \\
\text { - T compared } \\
\text { condiments with hot } \\
\text { chips in NZ cf target } \\
\text { culture. }\end{array}$ & $\begin{array}{l}\text { - T attempted links } \\
\text { between different } \\
\text { phrases she knew } \\
\text { would interest } \\
\text { the students eg. } \\
\text { English 'scaredy } \\
\text { cat' but in TL } \\
\text { 'scared rabbit.' }\end{array}$ & & \\
\hline
\end{tabular}

This teacher supported students to personalise their learning and to gain an understanding of their own environment. Learners were explicitly encouraged to notice similarities and differences and to link and explore language and culture. However, there were no observed opportunities for learners to reflect on their own culture through the eyes of others. There were also no observed opportunities for them to cross cultural boundaries and interact with a TL community, although this teacher reported in interview that she did have the benefits of a language assistant who came into class at other times to engage the students in TL conversation. Only one other teacher was observed operationalising the first three categories of the IcLL framework, but this was in a more limited way, providing learners with fewer 
opportunies. Another teacher was observed on one occasion encouraging learners to make a brief link between language and culture with one item of vocabulary, and also teaching a TL grammar structure so students could personalise their learning and talk about nationality and identity. Four of the seven teachers did not provide any opportunities to develop learners' Cultural Knowledge. We observed occasions where the "teaching moment" in terms of Cultural Knowledge was not maximised. For example, in one class the teacher provided a task for students to revise colours and clothes vocabulary (eg. red T-shirt, yellow dress etc). Students had to draw a washing line of clothes and name the items of clothing in the TL. There was no mention of the practice of drying clothes (strung up between apartment blocks) in the TL country compared with New Zealand (drying clothes in the open air on freestanding washing lines in urban gardens), nor possible reasons for these differences and what differences in lifestyle they represented. Visual illustrations of clothes drying in the two countries could have helped learners to recognise the links and the differences between aspects of the two cultures. Further discussion about how TL country visitors might view the New Zealand practice of drying clothes could have helped learners understand more about variations in accommodation and lifestyles in urban areas.

It is not surprising there was limited attention to culture in observed lessons, since teachers made no mention in interview of any sustained intention to provide opportunities to develop Cultural Knowledge. While teachers articulated language and communication lesson aims, from 15 interviews only four contained references to teachers having cultural aims. These were: looking for differences and similarities between teenagers in New Zealand and the target culture; comparing differences between New Zealand and target culture climate and seasons; understanding the special rules around mealtime and sharing food; and using TL structures for students to talk about themselves so they could become aware of the difference between nationality and cultural identity. 
In summary, interview and observation data revealed that teachers on the course were successful in providing opportunities for learners to develop their Language Knowledge. However, many teachers were not providing any, or sufficient, opportunities for students to gain Cultural Knowledge.

\section{Development of Knowledge Awareness}

In searching for the possible reasons for teachers' level of implementation of the Knowledge Awareness strand of the curriculum, we considered the Language Knowledge and Cultural Knowledge content in the three components of the professional development programme. Table 3 shows how the course content in each component contributed to the teachers' developing knowledge. 
Table 3. Opportunities for developing Knowledge Awareness through programme components

\begin{tabular}{|c|c|c|}
\hline Programme components & Language Knowledge & Cultural Knowledge \\
\hline SLA Methodology paper & $\begin{array}{l}\text { - Timetabled sessions focussed on } \\
\text { exploring principles based on SLA } \\
\text { research (Ellis, 2005). } \\
\text { - Comparison of old curriculum with } \\
\text { the new curriculum document. } \\
\text { - Over } 20 \text { recommended course } \\
\text { readings about pedagogy based on } \\
\text { SLA. } \\
\text { - Action research linked to Ellis } \\
\text { principles. } \\
\text { - Practical preparation for formative } \\
\text { and summative pedagogy tests } \\
\text { application of teaching materials to } \\
\text { Language Learning area of The } \\
\text { New Zealand Curriculum (2007). }\end{array}$ & $\begin{array}{l}\text { - Timetabled sessions with minimal } \\
\text { mention of developing cultural } \\
\text { knowledge. } \\
\text { - Noticing of place of culture in the } \\
\text { new curriculum document. } \\
\text { - Minimal recommended course } \\
\text { reading to develop cultural } \\
\text { knowledge. } \\
\text { - No action research related to aspects } \\
\text { of culture amongst case studies } \\
\text { - No assessment of Cultural } \\
\text { Knowledge strand. }\end{array}$ \\
\hline Language Study & - Increased Language Knowledge. & $\begin{array}{l}\text { - No mention of developing Cultural } \\
\text { Knowledge. }\end{array}$ \\
\hline In-School Support & $\begin{array}{l}\text { - Observation guidelines and post } \\
\text { teaching practice discussion } \\
\text { focussed on language development } \\
\text { aligned to Ellis principles. }\end{array}$ & $\begin{array}{l}\text { - Observation guidelines and post } \\
\text { teaching practice discussion had } \\
\text { limited focus on developing } \\
\text { Cultural Knowledge. }\end{array}$ \\
\hline
\end{tabular}

$\begin{array}{llll}\text { Notes TL } & \text { Target Language } & \text { SLA } & \text { Second Language Acquisition }\end{array}$

\section{SLA Methodology}

Language Knowledge was developed throughout the SLA methodology course in a number of ways. Course input focussed on exploring Ellis's (2005) principles based on SLA research (University of Auckland, 2008). From the beginning, sessions were based around exploration of one or more of these principles. Teachers saw them as valuable, frequently referring to them in interview. One teacher, in response to the question about what things were helping her improve her knowledge of how students learn language, replied, “Mr Ellis’s principles. It's so logical - why haven't they used them before!” Teachers also had opportunities to gain 
understanding on how to develop learners' Language Knowledge through discussions about the curriculum. The links teachers made with what they were doing in their classrooms were perceived as useful. One teacher said that "pulling apart" the 2007 curriculum document to understand it more fully was very helpful, while several teachers mentioned the comparison of the old curriculum with the new was also valuable in understanding the framework of what to teach. Three teachers specifically referred to the importance of using the language-based Ellis's language principles in their lesson planning. A further factor that contributed to the level of learning was the recommended readings. These supported and expanded on timetabled sessions in areas such as language acquisition, theoretical approaches, age for successful foreign language learning and introduction to the teaching of grammar and vocabulary. The strong focus on developing Language Knowledge influenced the teachers' subsequent choice of action research assignments; teachers all carried out projects exploring aspects of linguistic competence such as acquisition of vocabulary and assessment of oral production, rather than topics related to developing intercultural competence in their learners.

Finally, pedagogy tests assisted teachers' learning. A formative test followed by a summative test of curriculum knowledge assessed teachers' ability to practically align teaching materials with the Learning Languages area of The New Zealand Curriculum (2007). The focus here was on the application of language principles. Teachers saw the test as useful. Two commented beforehand on the pressure they felt, but once they had sat and passed the test and seen the practical application, the test's value was confirmed. As one commented, "I've got my head around the new curriculum ... it was a good test to see if we could apply it.” The assessment forced teachers to study and deeply process the curriculum's Language Knowledge strand.

The SLA methodology paper was thorough in its development of teachers' understanding of how to develop learners’ Language Knowledge. However, it was less successful in relation to 
Cultural Knowledge for several reasons. Firstly, although in the curriculum discussions there may have been opportunities to focus on the Cultural Knowledge strand, when the teachers were interviewed about their developing knowledge, none referred to knowledge of culture. Secondly, the recommended reading list, predominantly language based, had minimal readings on culture. This in turn may have affected the choice of topic for the teachers' action research projects. Finally, in the formative and summative pedagogy test, there was no attempt at assessing teachers' understanding of the Cultural Knowledge strand.

\section{Language Study}

The second component of the professional development programme was Language Study. Teachers' comments on the usefulness of the language study class they attended were related to learning more about language construction, for example grammar and pronunciation, as well ideas for teaching language in their own teaching context. Having to speak the language in class and receive feedback on the accuracy of their language also encouraged them as language learners. However, none of the teachers specifically mentioned any aspect of their language class that they found useful in developing their Cultural Knowledge. Again, another course component appeared to primarily develop Language Knowledge.

\section{In-School Support}

Through In-School Support, the teachers were provided with opportunities to apply their knowledge of teaching language and culture in their own classrooms. Facilitators provided the teachers with observation guidelines as a focus for lesson planning and delivery, and for post observation discussion. Eight of the twelve prompts related to language knowledge, formulaic chunks, negotiation of meaning, output, length of TL utterance, input, form, fluency. However, there was only one prompt relating to intercultural competence. As a 
result, teachers focussed on providing their learners with Language Knowledge, but were very limited in providing opportunities for learners to develop more understanding of culture.

\section{Learning theory}

The successful development of teachers' understanding of how to develop their learners' Language Knowledge can be attributed to the course content. A further reason for the successful development is linked to Sfard's (1998) theories of learning as manifested in the Acquisition Metaphor and Participation Metaphor. Teachers had the opportunity to acquire Language Knowledge and as well become part of a language teaching community. Table 4 shows the balance of acquisition and participation in the three components of the programme.

Table 4. Language Knowledge: Application of AM and PM on the three programme components.

\begin{tabular}{|c|c|c|}
\hline $\begin{array}{l}\text { Programme } \\
\text { Component }\end{array}$ & $\begin{array}{l}\text { Aspects of the course that can be viewed } \\
\text { through Acquisition Metaphor (cognitive) }\end{array}$ & $\begin{array}{l}\text { Aspects of the course that can be viewed } \\
\text { through Participation Metaphor (social) }\end{array}$ \\
\hline $\begin{array}{l}\text { SLA Methodology } \\
\text { paper }\end{array}$ & $\begin{array}{l}\text { - Action research based on readings and } \\
\text { inquiry } \\
\text { - Knowledge of the language strand of } \\
\text { the curriculum } \\
\text { - Assessment of pedagogy knowledge }\end{array}$ & $\begin{array}{l}\text { - Presentation of action research to other } \\
\text { course participants }\end{array}$ \\
\hline Language Study & $\begin{array}{l}\text { - Language Knowledge (eg. structures, } \\
\text { formulaic expressions) in language } \\
\text { study course }\end{array}$ & $\begin{array}{l}\text { - Participation in language study course } \\
\text { to increase TL proficiency } \\
\text { - Work-shopped principles of SLA in } \\
\text { language group meetings }\end{array}$ \\
\hline In-School Support & $\begin{array}{l}\text { - Progress of classroom practice } \\
\text { measured against criteria of effective } \\
\text { language learning principles }\end{array}$ & $\begin{array}{l}\text { - Post-observation reflective discussion } \\
\text { with course facilitator about evidence } \\
\text { of principles of effective language } \\
\text { learning. }\end{array}$ \\
\hline
\end{tabular}

$\begin{array}{lllll}\text { Notes } & \text { TL } & \text { Target Language } & \text { SLA } & \text { Second Language Acquisition }\end{array}$

The programme provided teachers with opportunities to acquire knowledge. Teachers were assessed on their knowledge of pedagogy, they gained knowledge of language features and formulaic expression through language study, and in In-School support teachers were given 
clear criteria to guide their teaching practice. All three programme components helped teachers construct and reconstruct knowledge for their own purposes. For example, teachers read texts on a topic of personal interest related to their own teaching practice. They then undertook action research in their own classrooms as a means of personal enrichment and to develop a greater understanding of effective language teaching.

As well as acquiring knowledge through individual study teachers also had opportunities for learning through participation. The individual knowledge gained through the action research project was shared with other course participants. Teachers mentioned the interest and benefits of this, indicating the intention to try out colleagues' findings within their own contexts. Teachers also became part of a language teaching community through discussion on pedagogy, taking part in a language study course and work-shopping the SLA principles in language group meetings. As the course progressed, they developed "the ability to communicate in the language of this community and act according to its particular norms” (Sfard, 1998, p.6). As one teacher mentioned, "I used to wonder what was going on with the curriculum. Now I can talk the talk.” Another teacher commented: "Now I feel expert in my knowledge of the learning languages area of the curriculum - I might take on a leadership role in my school.”

Sfard (1998) notes that each theory of learning has advantages, and a balance is desirable for effective learning. Application of Sfard's metaphors to this professional development programme demonstrates the programme is not in danger of having too great a devotion to one or other metaphor which can lead to "undesirable practices" (Sfard, 1998 p.4). We believe the balance of theories in the programme contributes to the success of teachers' development of Language Knowledge. 


\section{Principled knowledge base}

Timperly et al. (2007) suggest successful professional development programmes are founded on a deep principled knowledge base. The programme reported on in this paper is closely linked to the Generic Framework for Learning Languages (Ministry of Education, 2007b). The framework provides equal weighting, scholarly references and descriptions of Language Knowledge and Cultural Knowledge. However, there is one major difference in the framework between Language Knowledge and Cultural Knowledge. For Language Knowledge, ten general principles are identified for designing effective language programmes (Ellis 2005). The principles, drawn from SLA research, underpin the professional development programme and inform the content of the SLA Methodology paper and the In-School Support components. As a result of the emphasis on SLA principles, the programme focus is on teachers developing learners' linguistic knowledge and competence. We have shown that teachers do this very effectively, and can discuss and articulate the principles. However, as stated, teachers do not develop learners' Cultural Knowledge to the same degree.

Our findings are not dissimilar to ways teachers are reported to be operating in other contexts, ie. a focus on developing learners' linguistic competence rather than intercultural competence. A key reason suggested is teachers' uncertainty of how to teach intercultural competence (Woodgate-Jones, 2009; Sercu, 2006). Within the New Zealand context, we suggest their uncertainty arises from the fact that that Cultural Knowledge is not supported in the Generic Framework for Learning Languages (Ministry of Education, 2007b) by a set of principles in the same way as the Language Knowledge strand is. Understanding the central concepts of intercultural foreign language education is important for teachers before they can develop the skills to integrate them into their teaching (Sercu, 2006). In some contexts, there is a dynamic knowledge base of intercultural language teaching. In Australia, for example, 
researchers are working with experienced language teachers to explore what it means to teach language and culture. Teaching and Learning Languages: A guide (Scarino and Liddicoat, 2009), along with online sample teaching resources, provide teachers with the opportunity to engage with concepts and emerging principles of intercultural language learning. Current discussion centres around the tension between traditional language programmes and more current views central to intercultural language learning (see, for example, Scarino, 2008; 2009). However, it is still an emerging area in New Zealand. The main themes and principles underlying intercultural language teaching and learning have been discussed in the TESOL context, Newton (2008; 2009). Draft principles on Intercultural Communicative Language Teaching and learning have also been presented at a professional learning day for foreign language teachers of Years 7-10 students (NZALT, 2008) but are not yet published. The lack of a widely-available set of principles makes it difficult for educators to interpret the Cultural Knowledge intent of the Learning Languages area of The New Zealand Curriculum (2007) (Ministry of Education, 2007a), and thus for teacher educators to include this focus in their programme. We suggest the absence of principles contributes to the teachers' limited attempts to develop intercultural competence with their learners.

\section{Conclusion}

There is a need for language teachers who can fully operationalise the new Learning Languages area of The New Zealand Curriculum, (2007) (Ministry of Education, 2007a) to meet the Ministry of Education's expectation that all schools will be able to offer learners in Years 7-10 the opportunity to learn an additional language. We have reported on aspects of a Ministry-funded professional development programme to up-skill generalist and language teachers to teach additional languages. We have considered teachers' gains in providing opportunities to develop learners’ Language Knowledge, suggesting that a number of factors contribute to the programme's success in this area. The most important is the programme's 
tight links with the Generic Framework for Learning Languages (Ministry of Education, 2007b). Here, Language Knowledge is described clearly, and the ten principles for designing effective language programmes, drawn from SLA research, enable teachers to operationalise the intent of the curriculum. In addition, the programme offers participants a balance of learning through both acquisition and participation. In contrast, although there are scholarly references and a description of Cultural Knowledge in the Generic Framework for Learning Languages, the description is less clear. Furthermore, the lack of a clear set of principles underpinning Cultural Knowledge make it difficult for language teacher educators to design programmes that are effective in preparing language teachers to develop their learners' intercultural competence.

If as Sfard (1998) suggests the essence of learning is preparation for dealing with new situations likely to be encountered in the future, then the fact that most teachers were not providing opportunities to develop their learners' Cultural Knowledge is important. The area needs further consideration by policy makers, language teacher educators and teachers. Fundamental is the consideration and identification of intercultural language learning principles to further operationalise the intent of the Cultural strand of the Curriculum. Establishing and publishing a clear set of intercultural language learning principles will help to address the imbalance between teacher provision of opportunities for learners to develop Language Knowledge and Cultural Knowledge. Principles will also strengthen the Generic Framework for Learning Languages and provide a basis for teachers to explore and discuss ways to design more effective language programmes that develop intercultural speakers who can successfully engage with others across boundaries (Byram, 1995). 


\section{Reference List}

Bennett, J., Bennett, M. \& Allen, W. (2003). Developing intercultural competence in the language classroom. In D. Lange \& R. Paige (eds.) Culture as the core: perspectives on culture in second language education, 237-265. USA: Information Age Publishing.

Bransford, J., Brown, A, and Cocking, R. (1999). How people learn: Brain, mind, experience and school. Washington, D.C: National Academy Press. Retrieved May 7, 2010 from http://www.nap.edu/openbook.php?record_id=6160 .

Byram, M. (1995). Intercultural competence and mobility in a multi-national contexts: A European view. In M.L. Tickoo (ed.) Language and culture in multilingual societies, 21-26. Singapore: SEAMO Regional Language Centre.

Course outline EDPROFST360 Auckland. Auckland: University of Auckland. Retrieved October 20, 2008, from http://www.education.auckland.ac.nz/uoa/fms/default/education/lipis/docs/templates/ EDPROFST360_akl.doc

Crozet C. \& Liddicoat, A. (1999). The challenge of intercultural language teaching: Engaging with culture in the classroom. In J. Lo Bianco, A. Liddicoat \& C. Crozet (eds.), Striving for the third place: Intercultural competence through language education, 113-115. Melbourne: Language Australia.

Education Review Office. 2009. Readiness to implement the New Zealand Curriculum. Wellington: Education Review Office. Retrieved June 30, 2009, from http://ero.govt.nz/ero/publishing.nsf/Content/readiness-nz-curric-jan09 
Ellis, R. (2005). Instructed second language acquisition: A literature review. New Zealand: Ministry of Education. Retrieved November 20, 2007, from http://educationcounts.edcentre.govt.nz/publications/schooling/instructed_second_lan guage_acquisition

Elsen, A. \& St. John, 0. (2007). Learner autonomy and intercultural competence. In M. Raya and L. Sercu (eds.) Challenges in teacher development: learner autonomy and intercultural competence, 15-38. Frankfurt am Main: Peter Lang.

Erlam, R. (2005). Maximising instructional effectiveness in the language classroom. The New Zealand Language Teacher, 31, 38 - 40.

Gibbs, R. \& Holt, R. (2003). The teaching of international languages in New Zealand schools in Years 7 and 8: An evaluation study. Report to the Ministry of Education. Auckland: Auckland University of Technology.

Harvey, S., Conway, C., Richards, H., \& Roskvist. (2009). Evaluation of Teacher Professional Development Languages (in Years 7-10) and the impact on language learning opportunities and outcomes for students. Report to the Ministry of Education. Auckland: Auckland University of Technology.

Kramsch, C. (1993). Context and Culture in Language Teaching. Oxford: Oxford University Press.

Krashen, S. (1981). Second language acquisition and second language learning. Oxford, England: Pergamon.

Liddicoat, A., Papademetre, L., Scarino, A. \& Kohler, M. 2003. Report on intercultural language learning. Canberra: Australian Government, Department of Education, 
Science and Training. Retrieved 19 June, 2009 from

http://www.education.tas.gov.au/school/educators/resources/lote/cultural

Ministry of Education, (1999) Hai! An introduction to Japanese. International Language Series, Wellington: Learning Media.

Ministry of Education. (2007a). The New Zealand Curriculum (2007). Wellington: Learning Media.

Ministry of Education, (2007b). The generic framework for teaching and learning languages in English-medium schools. Wellington: Learning Media.

Newton, J. (2008, October). An intercultural stance on language teaching and learning: What's in it for TESOL in New Zealand? Paper presented at the $11^{\text {th }}$ National Conference for Community Languages and ESOL, Auckland, New Zealand.

Newton, J. (2009). A place for 'intercultural' communicative language teaching (iCLT) in New Zealand ESOL classrooms. TESOLANZ Journal, 17: 1-12.

NZALT (2008, September). An intercultural stance. Workshop presented at NZALT Auckland/Northland Branch, Professional Learning Day for Year 7-10 Language Teachers, Auckland, New Zealand.

Nikolov, M. \& Djigunović, J. (2006). Recent research on age, second language acquisition and early foreign language learning. Annual Review of Applied Linguistics, 26: 234260.

Scarino, A. (2008). Reconceptualising learning programmes for intercultural language learning. Babel, 43, 1: 7-9, 35, 38. Retrieved June 18, 2009 from http://search.informit.com.au.ezproxy.aut.ac.nz/fullText;dn=200900425;res=APAFT 
Scarino, A. (2009). Reflecting on the use of the professional standards for accomplished teaching of languages and cultures. Babel, 44, i1: 4(5). Retrieved December 3, 2009 from http://galenet.galegroup.com.ezproxy.aut.ac.nz/servlet/IOURL?locID=Loc_ID\&issn= 0005-3503\&prod=LitRC\&finalAuth=true

Scarino, A. \& Liddicoat, A. (2009). Teaching and learning languages: A guide. Carlton South, Australia: Australian Government Department of Education, Employment and Workplace Relations.

Sercu, L. (2006). The foreign language and intercultural competence teacher: the acquisition of a new professional identity. Intercultural Education, 17, 1: 55-72.

Sfard, A. (1998). On two metaphors for learning and the dangers of choosing just one. Educational Researcher, 27: 4-13.

Timperley, H., Wilson, A., Barrar, H. \& Fung, I. (2007). Teacher professional learning and development: Best evidence synthesis iteration. Wellington, New Zealand: Ministry of Education. Retrieved October 10, 2008, from http://educationcounts.edcentre.govt.nz/goto/BES

University of Auckland. (2008). [Course outline for EDPROFST360.] Retrieved October 20, 2008, from http://www.education.auckland.ac.nz/uoa/fms/default/education/lipis/docs/templates/ EDPROFST360_akl.doc

Woodgate-Jones, A. (2009). The educational aims of primary MFL teaching: an investigation into the perceived importance of linguistic competence and intercultural understanding. Language Learning Journal, 37: 255-265. 